\title{
COMMENTS
}

\section{AUTHORITY OF THE SECRETARY OF STATE TO DENY PASSPORTS}

Since 1941 it has been unlawful for a United States citizen to leave the western hemisphere without a passport. ${ }^{1}$ Issuance of passports is controlled by the Department of State and administered by its Passport Office. ${ }^{2}$ In the past decade, the Secretary of State has claimed authority to deny and has denied passports where, in his opinion, the national interest required it. $^{3}$

Of the cases which have arisen in the federal courts as a result of these denials, one of the most important is the recent case of Briehl $v$. Dulles. ${ }^{3 a}$ Briehl, a psychiatrist, applied to the Department of State for renewal of his passport for purposes of attending international mental health congresses at Geneva and Istanbul. The Passport Office requested him to furnish an affidavit as to past or present membership in the Communist Party in accordance with section $\mathbf{5 1 . 1 4 2}$ of the Passport Regulations of the Secretary of State. ${ }^{4}$ Briehl refused and the Passport Office announced a tentative denial of his application under section 51.135 of the Regulations which places restrictions on the issuance of passports to "persons supporting [the] Communist movement." 5 At a subsequent informal hearing Briehl

1. The United States passport has been defined as "a document of identity and nationality issued to persons owing allegiance to the United States and intending to travel or sojourn in foreign countries." 3 HACKWORTH, DIGEST OF INTERNATIONAL LAW 435 (1942). See DePARTMENT OF State, THE A MERICAN PASSPort 3-6 (1898). Throughout most of American history a passport was a convenience and not a necessity to foreign trave1. Id. at 3,4,46,54. Since 1815, however, Congress or the Secretary of State has made it illegal, with certain exceptions, to leave the country without a valid passport during each of our major wars. 3 STAT. 199 (1815); DEPARTMENT OF STATE, op. cit. supra at 50; 40 STAT. 559 (1918), 22 U.S.C. \$§ 223-26 (1952) (implemented by Presidential Proclamation No. 1473, (1918)). The act of 1918 was extended to "national emergencies" in 1941. 55 STAT. 252 (1941), 22 U.S.C. \& 223 (1952), superseded by 66 STAT. 190, 8 U.S.C. $\$ 1185$ (b) (1952). Despite the general requirement of a passport, there are still a few western hemisphere countries where passports are not required either by the United States or the visited country. Since, however, most countries today require passports for entrance, passports would remain a necessity for foreign travel even if it were made lawful to leave the United States without one. Comment, Passport Refusals for Political Reasons: Constitutional Issues and Judicial Review, 61 Y ALE L.J. 171-72 (1952); Hearings Before Subcommittee No. 1 of the House Committee on the Judiciary, 84th Cong., 2d Sess., ser. 24, at 27 (1956).

2. 44 STAT. 887 (1926), 22 U.S.C. § 211 a (1952); 22 C.F.R. § 51.101 (1949).

3. See Comment, Passport Refusals for Political Reasons: Constitutional Issues and Judicial Review, 61 YALE L.J. 171, 174-78 (1952).

3a. 248 F.2d 561 (D.C. Cir. 1957), cert. granted sub non. Kent v. Dulles, 26 U.S.L. WEEK 3166 (U.S. Nov. 26, 1957) (No. 481).

4. 22 C.F.R. $\$ 51.142$ (Supp. 1957).

5. Id. $\S 51.135$. 
again declined to execute the affidavit, whereupon the Passport Office informed him that it knew of no further action which it could take in his behalf. Briehl then brought an action in the District Court for the District of Columbia to compel the Secretary of State to renew the passport. A motion by the Secretary for summary judgment was granted ${ }^{6}$ and the court of appeals, sitting en banc, affirmed 5-3, holding that the regulations invoked by the Secretary were valid and Briehl, by failing to file the affidavit required by them, had disqualified himself for a passport.

The Secretary of State has long claimed an almost unlimited discretion to deny passports on the grounds that (1) the Executive has inherent power to act independently in foreign affairs, and passport regulation is a legitimate exercise of the foreign affairs power; and (2) the Legislature has delegated to the Executive in broad terms whatever authority it possesses in this area. ${ }^{7}$ The purported congressional delegation is based primarily on a 1926 statute, the relevant provisions of which do not set forth any standards for executive action but state simply that the Secretary "may grant ... passports under rules and regulations established by the President." 8 The Secretary, in promulgating the substantive regulations invoked in the Briehl case, purported to base the statutory authorization for them only on this act; ${ }^{9}$ but the majority of the court found the Secretary's substantive statutory authorization reaffirmed in a 1952 act which, also without establishing clear standards, makes passports necessary for foreign travel. ${ }^{10}$

Judicial interpretation of the limits of the Secretary's discretion in issuing passports was notably lacking until after World War II. ${ }^{11}$ Prior to a

6. Briehl v. Dulles, 248 F.2d 561 (D.C. Cir. 1957).

7. Brief for Appellee, p. 29, Briehl v. Dulles, 248 F.2d 561 (D.C. Cir. 1957); 3 HAckworTH, op. cit. sitpra note 1, at 467-70. See Urtetiqui v. D'Arcy, 34 U.S. (9 Pet.) 692, 698 (1835).

8. 44 Srar. 887 (1926), 22 U.S.C. § 211a (1952); Brief for Appellee, p. 29, Briehl v. Dulles, 248 F.2d 561 (D.C. Cir. 1957). A related statute restricts issuance of passports to persons owing allegiance to the United States. 32 Srar. 386 (1902), 22 U.S.C. $\$ 212$ (1952). The authority conferred on the President was exercised through Exec. Order No. 7856, 3 FED. REG. 799 (1938); see also 22 C.F.R. $\$ \$ 51.1-.77$ (1949). Aside from the requirement that American passports may be granted only to persons owing allegiance to the United States, the President's regulations are largely procedural in nature. Section 51.75 authorizes the Secretary "in his discretion to refuse to issue a passport," and § 51.77 empowers the Secretary to make "regulations on the subject of issuing ... or withdrawing passports additional to the rules in this part and not inconsistent therewith."

9. The Internal Security Act of 1950 provides that a member of a registered communist-action organization or an organization finally ordered to register under the act is not entitled to a passport. 64 STAT. 993 (1950), 50 U.S.C. $\S 785$ (1952). However, no such final order has yet been issued. See Communist Party v. Subversive Activities Bd., 351 U.S. 115 (1956).

10. Based on a statute of 1941, the statute in its present form provides, that ". . . it shall, except as otherwise provided by the President, and subject to such limitations and exceptions as the President may authorize and prescribe, be unlawful for any citizen of the United States to depart from or enter, or attempt to depart from or enter, the United States unless he bears a valid passport." 66 STAT. 190, 8 U.S.C. $\S 1185$ (b) (1952).

11. In one of the few pre-war challenges of the Secretary's discretion the Supreme Court precluded denial of a passport solely on the basis of an erroneous determination of citizenship or non-citizenship. Perkins v. Elg, 307 U.S. 325 (1939). 
few months before entry of the United States into the war, the absence of a passport did not confine the citizen to the Americas except in time of war, ${ }^{12}$ and there is little evidence that the Secretary had denied passports to any but a very limited class of persons during peacetime. ${ }^{13}$ With the advent of the post-war period, however, the Passport Office began denying passports solely on the ground that the "best interests" of the United States required it:14 unsuccessful applicants, who were generally granted neither hearing nor further explanation, ${ }^{15}$ sought judicial relief. One of the first tests of the "best interests" refusals was Baner v. Acheson.16 Although the court seemed to assume a broad discretion in the Secretary to deny passports, it ruled that this discretion was not unlimited since it conflicted with the right of the individual to travel abroad, a right protected by the due process clause of the fifth amendment. It therefore interpreted the 1926 statute to require notice and an opportunity to be heard before a passport may be denied. ${ }^{17}$ Later decisions have elaborated upon the procedural safeguards to be afforded the applicant and have held that such standards for denial as are adopted by the Secretary must be applied equitably. In Nathan v. Dulles ${ }^{18}$ and Clark v. Dulles, ${ }^{19}$ the court held that an informal investigation and correspondence between the applicant and the State Department did not meet the hearing requirement. Boudin $v$. Dulles ${ }^{20}$ and Dayton v. Dulles ${ }^{21}$ decided the factual findings sufficient to bring the applicant within one of the classes to be denied passports described in the Passport Regulations are necessary before the Secretary may deny a passport under the authority of those regulations. In Kraus $v$. Dulles ${ }^{22}$ it was held that before the court would consider whether the Secretary could require the applicant to show that he could support himself abroad, the Secretary had to show satisfactorily what the Department's policy was in regard to a "means" test and how such test was ap-

12. See note 1 supra.

13. "As a general rule the Department bases the issue of a passport on purely citizenship grounds, although this is not an inflexible rule and is modified in individual cases based upon the particular facts in each case." The Department of State to the Consul General at Barcelona, Nov. 18, 1933, MS. Dept. of State, file 138/3224, quoted in 3 HACKWORTH, op. cit. supra note 1, at 512. For cases where passports were denied on grounds other than lack of citizenship prior to the end of World War II, see id. at $498-512,530-32$.

14. The "best interests" refusals generally involved persons with alleged connections of one kind or another with international communism. Comment, Passport Refusals for Political Reasons: Constitutional Issues and Judicial Reviez, 61 YaLE L.J. 171, 173-78 (1951).
15. Ibid.
16. 106 F. Supp. 445 (D.D.C. 1952).
17. Id. at $451-52$.
18. 129 F. Supp. 951 (D.D.C. 1955).
19. 129 F. Supp. 950 (D.D.C. 1955).
20. 235 F.2d 532 (D.C. Cir. 1956).
21. 237 F.2d 43 (D.C. Cir. 1956).
22. 235 F.2d 840 (D.C. Cir. 1956). 
plied. ${ }^{23}$ Shachtman v. Dulles, ${ }^{24}$ the first of the cases to apparently deal with the substantive authority of the Secretary to deny passports rather than with procedural due process problems, held that it was a violation of substantive due process to deny a passport solely on the grounds that the applicant was a member of an organization improperly listed as subversive by the Attorney General. ${ }^{25}$ But though it stated that such a denial would be arbitrary and "without a reasonable relation to foreign affairs," the court did not rule on whether the passport should or should not be issued in the event of a proper determination by the Attorney General nor did it otherwise consider the validity of the Secretary's Regulations. ${ }^{26}$ The case could be said to stand only for the proposition that the Secretary must give reasons for denial sufficient to bring the applicant within the Regulations.

Nathan, Clark, Boudin, Dayton, Kraus and Shachtman assumed broad discretion in the Secretary to deny passports but rejected the notion that this discretion is absolute by providing the applicant with certain largely procedural safeguards. Procedural safeguards mean little, however, if ultimately the Secretary may refuse a passport on virtually such substantive grounds as he deems sufficient. The more basic question of the Secretary's authority to establish substantive standards was for the first time brought into sharp focus by the Briehl decision. In affirming denial of Briehl's passport for failure to provide an affidavit, the court upheld the validity of the requirements for passport eligibility embodied in the Regulations to which the information sought in the affidavit was relevant. ${ }^{27}$ The court did not clearly delineate the scope of the Secretary's authority. It found merely that its source was in the foreign affairs area and that the totality of power in this area is possessed by the executive and legislative branches of the Government. ${ }^{28}$ Such power as Congress may have, it delegated to the Secretary through the President by statute. The court believed its scope of review limited to a determination of whether the Secretary "so far violated constitutional prescriptions or specific constitutional limitations as to cast his action outside the exceedingly broad boundaries within which he is free to act without judicial review." 29 Finding justification for the Regulations in question in the dangers presented by the international Communist movement, the court concluded that the interests of the Government outweighed those of the individual..$^{30}$

Of the claimed bases of the Secretary's right to formulate substantive standards, the first is the Executive's inherent power to act independently

23. Existing departmental regulations do not provide for a "means" test for applicants. 22 C.F.R. $\$ \$ 51.101-.143$ (Supp. 1956).

24. 225 F.2d 938 (D.C. Cir. 1955).

25. The procedural posture in which the case reached the court required it to construe the facts most favorably to the applicant. Id. at 942 .

26. Id. at 943.

27. Briehl v. Dulles, 248 F.2d 561, 576 (D.C. Cir. 1957).

28. Id. at 566 .

29. Id. at 568 .

30. Id. at $575-76$. 
in foreign affairs. Courts have established that this power does not preclude them from taking cognizance of passport cases, but they claim, as in Briehl, that it narrows the scope of the inquiry. ${ }^{31}$ In practice, since the Baner decision the courts have closely scrutinized several largely procedural facets of the Secretary's authority, 32 and the inherent power doctrine has lost much of the force it presumably once had in passport cases. It still frequently appears in the language of the opinions, however, and seems to have retained sufficient vitality to serve as a make-weight in the process of balancing the equities in each case.

The inherent power doctrine developed from judicial reluctance to intervene in problems arising from Executive policy decisions pertaining to relations between the United States and foreign governments. Courts have refused to interfere in matters concerning recognition of foreign governments, ${ }^{33}$ determination of disputed sovereignties, ${ }^{34}$ termination of treaty obligations, ${ }^{35}$ and prohibition of the sale of munitions to certain countries. $^{36}$ But these cases, as noted by Judge Bazelon dissenting in Briehl, did not involve a situation " where the Executive action was specifically directed at restraining the freedom of a particular individual." "37 They can thus be distinguished from the cases arising from passport denials and do not compel the conclusion that the Secretary's discretion in the passport area is absolute, i.e., that the court is without power to review the merits of his decisions. It is true that the use of a passport can have an impact upon foreign affairs. But to the extent that eligibility requirements for a passport restrict certain individuals in the exercise of their

31. The Briehl court stated: "There are of course in any government formed upon a constitution residual areas within which the judicial branch may act in respect to a power even so unfettered as is the executive power in foreign affairs. If the President were in gross defiance of constitutional limitations, or perhaps even of congressional prohibitions, the judiciary might act. . . . It must be kept in mind that the power of the judiciary to inquire is vastly different from its power to act. A court often has jurisdiction to determine whether it has jurisdiction. The books are full of cases in which the courts have examined with meticulous care complaints alleging invalidity of executive action in foreign affairs. But seldom if ever have the courts found grounds to impose upon such executive action their own ideas of propriety or wisdom. So in the case at bar it is not suggested that the court could not entertain a complaint against the Secretary of State alleging the illegality of his action. The point is that having examined the allegations the court is without power to act save in a narrow and limited class of extraordinary circumstances." Id. at 567-68.

32. See cases cited at notes 18-22, 24 supra.

33. Oetjen v. Central Leather Co., 246 U.S. 297 (1918); Jones v. United States, 137 U.S. 202 (1890).

34. Foster v. Neilson, 27 U.S. (2 Pet.) 253 (1829).

35. Terlinden v. Ames, 184 U.S. 270 (1902) ; Ivancevic v. Artukovic, 211 F.2d 565 (9th Cir. 1954).

36. United States v. Curtiss-Wright Export Corp., 299 U.S. 304 (1936).

37. Brieh1 v. Dulles, 248 F.2d 561, 590 (D.C. Cir. 1957). But see Fahey v. Mallonee, 332 U.S. 245 (1947) (delegation without stating standards by Home Owners' Loan Act of power to provide through regulations for the liquidation of savings and loan associations); Federal Power Comm'n v. Hope Natural Gas Co., 320 U.S. 591 (1944) (statute authorized Commission to fix "just and reasonable" rates for natural gas); Intermountain Rate Cases, 234 U.S. 476 (1914) (Interstate Commerce Act authorized Commission to make exceptions to policy against charging more for short than for long hauls, but stated no standard), discussed in Davis, AdmINISTRATIve Law $\S \S 13-14$ (1951). 
constitutionally protected rights of freedom of movement and expression ${ }^{38}$ there appears to be no reason why the same constitutional limitations should not be applicable to executive regulation as would be applicable to a legislative restriction of those same rights in related fields. ${ }^{39}$ That the nation's foreign interests are involved may provide a reason for some limitation on individual freedom, just as, for example, internal security provides a reason for some limitation on free speech as in the Smith Act. ${ }^{40}$ It does not provide a reason for absolute discretion to deny passports being lodged in the Secretary of State anymore than does internal security give Congress absolute discretion to limit exercise of the right of free speech. ${ }^{41}$ The fact that foreign affairs are involved should not preclude all judicial review on the merits but should only require that courts give proper weight to United States interests as opposed to individual interests when considering whether a particular restraint exceeds constitutional limitations.

Though the Secretary may not have unlimited discretion to frame passport regulations, executive control over foreign affairs may confer some authority on him to prescribe such regulations. Thus, it might be argued that apart from any statutory grant, the Secretary would have power to determinate eligibility requirements so long as they did not contravene constitutional limitations analogous to those imposed on legislative restrictions of personal liberties. Even this limited implication of inherent power in the Secretary, however, seems improper in view of the direct impact its exercise would have upon individual liberties. The sounder position would require that basic policy decisions with regard to limitations of this sort be made by Congress, politically a more responsive body than an administrative officer. The court's role would then be to ap-

38. Briehl v. Dulles, 248 F.2d 561, 573-75 (D.C. Cir. 1957) ; Bauer v. Acheson, 106 F. Supp. 445, 451 (D.D.C. 1952); Shachtman v. Dulles, 235 F.2d 938 (D.C. Cir. 1955) (concurring opinion). See Jaffe, The Right To Travel: The Passport Problem, Foreign Affairs, Oct. 1956, p. 17; Wyzanski, Freedom To Travel, Atlantic Monthly, Oct. 1952, p. 66.

39. A test used to decide the constitutional limitations on legislative restrictions of an individual's freedom of expression is the "clear and present danger" doctrine. This doctrine was first announced by Justice Holmes in Schenck v. United States, 249 U.S. 47, 52 (1919): "The question in every case is whether the words are used in such circumstances and are of such a nature as to create a clear and present danger that they will bring about the substantive evils that Congress has a right to prevent." It was accepted by later Supreme Court jurists as a "working principle that the substantive evil must be extremely serious and the degree of imminence extremely high before utterances can be punished." Bridges v. California, 314 U.S. 252, 263 (1941). Recent decisions involving the Communist Party have perhaps modified the doctrine somewhat. In Dennis v. United States, 341 U.S. 494 (1951), the Court upheld the conviction of Communist Party leaders under the Smith Act and four members of the majority espoused the doctrine as interpreted by Judge Hand in the court below: "In each case [courts] must ask whether the gravity of the 'evil,' discounted by its improbability, justifies such invasion of free speech as is necessary to avoid the danger." 183 F.2d 201, 212 (2d Cir. 1950). On the basis of this decision it may be that the danger no longer has to be very imminent, but the recent case of Yates $v$. United States, 354 U.S. 298 (1957), perhaps limits Demis in this respect by establishing that speech advocating the overthrow of the Government cannot be proscribed unless "those to whom the advocacy is addressed [are] urged to do something, now or in the future, rather than merely to believe in something. . . ." Id. at 325.

40. 18 U.S.C.A. \$ 2385 (Supp. 1956).

41. See note 39 sitpra. 
ply established constitutional doctrines to resulting statutes as implemented by executive regulations. ${ }^{42}$ In so doing it would have the benefit of congressional investigation and consideration as well as administrative knowledge and experience. The ultimate determination by the court as to whether a proper balance had been struck between individual and national interests should be superior to that possible when only an administrative officer has weighed the problem in advance of the court. It should therefore be declared that the Secretary's authority to determine who shall be eligible for a passport rests not on any inherent power doctrine but on statutory grant. Two additional results may follow: the Secretary would perhaps be restrained by the threat of legislative curtailment of his authority ; and the Congress might be induced to give fuller consideration to the problem than has heretofore been the case. ${ }^{43}$

The court in Briehl, assuming that some control over that portion of foreign affairs relating to passports rests in part in Congress, held that such power as Congress possessed had been delegated by the statutes of 1926 and 1952 to the Executive. The statute of $1926,{ }^{44}$ providing that the Secretary "may grant . . . passports under rules and regulations established by the President," devolved from a similar act of $1856 . .^{45}$ A State Department publication of 1898 indicates that the primary purpose of the act of 1856 was to insure that passports were issued only by the Secretary of State. ${ }^{46}$ Legislative history of the 1926 statute gives no indication as to whether Congress intended to confer power on the Secretary to prescribe substantive eligibility requirements for a passport or whether it merely intended to confer power to establish appropriate procedures for the issuance of passports. ${ }^{47}$ The purpose of the 1952 statute ${ }^{48}$ making it unlawful

42. Ibid.

43. Senator Fulbright of Arkansas introduced a bill (S.2770, 85th Cong., 1st Sess.) on the Senate floor on Aug. 13, 1957, which would authorize the Executive to deny passports only when (1) "there is good reason to believe that ... the citizen or his activities abroad will violate the laws of the United States"; or (2) the citizen "is a member of the Communist Party or a member of an organization which has been finally ordered by the Subversives Activities Control Board to register or has recently terminated such membership under such circumstances as to warrant the conclusion, not otherwise rebutted by the evidence, that he continues to act in furtherance of the interests and under the discipline of the Communist Party or such organization"; or (3) "the citizen owes the government of the United States money for previous transportation back to the United States." The bill contains a statement of policy which provides: "Travel by citizens abroad shall be as free of governmental restraint as possible consistent with the requirements of national security." 103 CoNG. REc. 13175-77 (daily ed. Aug. 13, 1957). The bill was submitted to the Senate Committee on Foreign Relations, 103 Cong. Rec. 13173 (daily ed. Aug. 13, 1957) but was not reported out of committee by the end of the session.

44. 44 STAT. 887 (1926), 22 U.S.C. \$211a (1952).

45. 11 STAT. 60 (1856).

46. Legislative history of the 1856 act is sparse. According to the Department publications, the other main purpose was apparently to restrict passport issuance to American citizens. Department of State, The American Passport 43-44, 48 (1898). See Boudin, The Constitutional Right To Travel, 56 Colum. L. REv. 47, $52-53$ (1956); Doman, A Comparative Analysis: Do Citizens Have the Right To Travel?, 43 A.B.A.J. 307, 308 (1957).

47. 67 Cong. REc. 11705-06 (1926).

48. See note 1 supra. 
to travel outside the western hemisphere without a passport and found in Briehl to reaffirm the Secretary's power is also in doubt. Legislative debates on the 1918 act from which the 1952 act's travel control provisions derive are susceptible of the interpretation that the statute may only have been designed to place general restrictions on travel to certain countries. ${ }^{49}$ The debates on the 1918 bill could also be read, however, to indicate that Congress may have intended to keep certain citizens from going abroad during wartime or time of national emergency and made the Secretary the agent through which this objective was to be accomplished. ${ }^{50}$ Although the language of neither statute compels the result, the court in Briehl elected to interpret them broadly so as to confer on the Secretary a maximum of discretion.

If the 1926 and 1952 acts, implemented by executive orders, lodge in the Secretary broad discretion to deny passports, two problems are raised. The first is whether the statutes so interpreted represent excessive delegations of legislative power. And if the delegations are not excessive, what, if any, constitutional limitations restrict the Secretary's exercise of that power. Judge Bazelon's dissent in Briehl would have avoided these issues by adopting a narrower interpretation of the statutes. ${ }^{51}$ It would have held the 1926 act to merely confer power on the Secretary to prescribe procedural regulations for the securing of a passport ${ }^{52}$ and the 1952 act to mean that the President might establish conditions and exceptions to the prohibition against travel but not that he may "decide which categories of citizens might receive passports." 53

In only two cases has the Supreme Court declared a federal statute invalid on the ground that it represented an excessive delegation of legislative authority to an administrative agency. ${ }^{54}$ In a number of cases in-

49. Representative Flood, Chairman of the House Committee on Foreign Affairs which reported the House bill, replying to questions as to whether the bill would allow the Executive to proclaim which persons shall or shall not receive passports, stated that the Executive could make determinations as to "particular places or particular persons." Since a considerable portion of the debate during which this remark was made concerned whether the bill would necessitate passports for travel to Canada and Mexico, it may be that the reference was to "particular persons" desiring to go to particular countries. 56 CoNG. REc. 6029-32, 6061-67 (1918); See Comment, The Passport Puzzle, 23 U. CHr. L. Rev. 260, 272-73 (1956).

50. Representative Flood said that the purpose of the bill was to give the Executive power "to control ingress and egress from this country." 56 CoNG. Rec. 6029 (1918). See note 49 sitpra.

51. Judge Washington, concurring in Briehl, suggested, that the court need not determine the full scope of the statutory grant and the regulations, since the Secretary had not yet made a final decision on the application but had made only "an official determination ... not to render a final decision on the matter because of Dr. Briehl's refusal at his hearing to furnish an affidavit. ..." He concluded that the only question raised by the appeal was whether the Secretary may validly require such an affidavit as a condition precedent to the rendering of a final decision. Briehl v. Dulles, 248 F.2d 561, 576-79 (D.C. Cir. 1957) ; cf. Stewart v. Dulles, Civil Nos. 13533, 13622, 13638, D.C. Cir., July 3, 1957 (applicant submitted affidavit that he had not been Communist Party member at any time during the past fifteen years).

52. Briehl v. Dulles, 248 F.2d 561 (D.C. Cir. 1957).

53. $I d$. at 582 .

54. Schechter Poultry Corp. v. United States, 295 U.S. 495 (1935) ; Panama Refining Co. v. Ryan, 293 U.S. 388 (1935). 
volving state statutes granting authority to administrative agencies to place prior restraints on the exercise of first amendment rights, the Court has found the delegation accompanied by insufficient standards. ${ }^{55}$ If the 1926 statute is interpreted to confer authority on the Secretary to promulgate eligibility requirements for a passport, it would seem to fall within the latter category. Without prescribing standards, it would authorize the Secretary to restrict an individual in the exercise of his right to move about freely and to communicate with others while abroad in advance of a showing that the individual's movement or communication would harm the United States' interests. This difficulty would seem to dictate a narrower interpretation of the statute as the dissent in Briehl suggested. The act of 1952 makes illegal departure from or entry into the United States without a valid passport "when the United States is at war or during the existence of any national emergency proclaimed by the President, . . . and the President . . . find[s] that the interests of the United States require that restrictions and prohibitions in addition to those provided otherwise than by this section be imposed upon the departure . . . from and ... entry into the United States. ..." 56 Reference to war or a state of national emergency in this statute may be a sufficient standard to support the validity of passport regulations relevant to those conditions. The court's finding in Briehl that regulations preventing issuance of passports to communists or communist sympathizers are relevant to the conditions underlying the subsisting Korean national emergency is probably correct. ${ }^{57}$ Thus, though the 1926 statute when read alone and interpreted broadly may represent an improper delegation of legislative power, the 1952 statute appears to provide the necessary standard to support the Secretary's exercise of authority to promulgate substantive regulations.

Assuming that the Secretary's exercise of authority to frame substantive passport regulations is supported by valid statutes, there would remain the problem of determining whether the regulations promulgated exceed constitutional limitations. This would require a balancing of the applicant's interests in exercise of his constitutional rights against the interests of the United States in forbidding travel where it might be expected to be detrimental to our foreign policy or national defense..$^{58}$ The court in Briehl did not face this issue squarely since it found its scope of review extremely narrow. It is to be hoped that federal courts in the future will reject this narrowing of the scope of review and permit the making of a record which will afford them a basis for weighing the competing interests and determining the validity.of the Secretary's Regulations.

55. Niemotko v. Maryland, 340 U.S. 268 (1951) (practice of requiring permits for public meetings or speeches in public park contrary to first and fourteenth amendments); Kunz v. New York, 340 U.S. 290 (1951) (city ordinance giving administrative official discretionary power to control in advance right of citizens to speak on religious matters on city streets invalid under first and fourteenth amendments).

56. 66 STAT. 190, 8 U.S.C. $\$ 1185$ (1952).

57. Briehl v. Dulles, 248 F.2d 561, 576 (D.C. Cir. 1957).

58. See note 39 supra. 